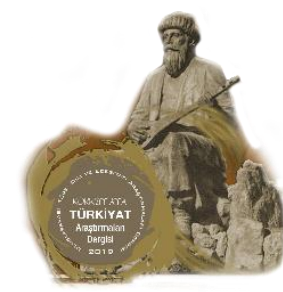

\author{
KORKUT ATA TÜRKİYAT ARAŞTIRMALARI DERGİṠ \\ Uluslararası Türk Dili ve Edebiyatı Araştırmaları Dergisi \\ The Journal of International Turkish Language $\mathcal{E}$ \\ Literature Research
}

|| Sayı/Issue 5 (Ağustos/August 2021), s. 299-315.

Geliş Tarihi-Received: 06.07.2021

Kabul Tarihi-Accepted: 17.08.2021

Araştırma Makalesi-Research Article

ISSN: $2687-5675$

DOI: $10.51531 /$ korkutataturkiyat.963031

\title{
Zara (Sivas) Ağzından Derleme Sözlüğüne Katkılar II
}

\author{
Contributions To The General Dialect Dictıonary From The Town Zara (Sivas) II
}

\section{Ömer GÜVEN*}

Öz

\begin{abstract}
Ağızlar; kitle iletişim araçlarının yaygınlaşması, eğitim düzeyinin yükselmesi, köyden kente göç gibi nedenlerle yok olma tehlikesi altındadır. Bu sebeple; ağızların söz varlığına dair tespit edilip kayda geçirilen her bir kelime, deyim vs. çok önemlidir. Metin derlemesi yanında sözcük derlemeleri de bu noktada önem taşımaktadır. Bu önemli dil verilerinin kaybolmaması için derleme çalışmalarının vakit kaybetmeden yapılması gerekmektedir. Bu nedenle derleme çalışmalarının önemi son yıllarda giderek artmıştır.
\end{abstract}

Bu çalışma daha önce yayınladığımız Zara (Sivas) A ğzından Derleme Sözlü̆̆üne Katkılar adlı çalışmanın devamı niteliğindedir. Adı geçen çalışmadan sonra yaptığımız araştırma ve incelemelerde elde edilen dil verileri bu çalışmada ele alınmıştır. Çalışmada dil verileri Zara ağzında kullanılan ve Derleme Sözlüğ̈̈'nde yer almayan kelimeler ile Derleme Sözlüğ̈̈'nde bulunan ancak Zara ağzında farklı anlam barındıran kelimeler olarak sınıflandırılmıştır.

Belirlenen kelimeler; deyimler, adlar, sıfatlar, zarflar, ünlemler, fiiller, beddualar, ikilemeler başlığı altında tasnif edilerek ele alınmıştır. Çalışmada, bu söz varlıklarının fonetik özelliklerini yansıtmak amacıyla transkripsiyon işaretleri kullanılmıştır. Yaptığımız bu çalışmayla asıl gayemiz Derleme Sözlüğ̈̈' nün yapılacak yeni baskılarına az da olsa bir katkı sunmaktır.

Anahtar Kelimeler: Ağız bilimi, Derleme Sözlüğü'ne katkılar, Türkiye Türkçesi ağızları, Zara ağzı.

\begin{abstract}
The dialects are under threat of extinction for reasons such as the proliferation of mass media, the rise of the education level and the migration from villages to the cities. Therefore, each word, phrase, proverb etc that are detected and registered relating to the lexicon of the dialects are very important. In addition to text compilation, word compilations are also important at this point. In order not to lose this important language data, word collection should bo done without wasting time. Fort his reason, importance of studies on word collection has more increased.

This work is a follow-up to the work titled "Contributıons to the General Dialect Dictionary (Derleme Sözlüğ̈̈) from the Town Zara (Sivas)", which we previously published. After the mentioned study, the language data obtained in the researches and examinations we conducted were discussed in this study. In the study, the language data were classified as words used in Zara dialect and not included in the General Dialect Dictionary and words found in the General Dialect Dictionary but having different meanings in Zara's dialect.
\end{abstract}

These linguistic materials are classified and analysed under the rubrics of idioms, nouns, adjectives, adverbs, exclamations, verbs, curse and reduplication. In the study transcript signs

\footnotetext{
* Arş. Gör. Dr., Amasya Üniversitesi, Fen-Edebiyat Fakültesi, Türk Dili ve Edebiyatı Bölümü, e-posta: omer.guven@amasya.edu.tr, ORCID: https://orcid.org/0000-0002-9376-3538.
} 
of words are used in order to reflect the phonetic properties. Our main purpose in this study is to make contribution to Dictionary of Turkish Dialects.

Keywords: Dialectology, contributions to the General Dialect Dictionary, Turkey Turkish dialects, Zara dialect.

\section{Giriş}

Türk kültürünün ve medeniyetinin en önemli kaynaklarından biri Türk dilidir. 8 . yüzyıldan beri yazılı metinlerle takip edilebilen Türkçe, bu tarihî seyri içinde pek çok değişime ve gelişime sahne olmuştur. Bu değişim ve gelişimi bulabileceğimiz alanlardan biri de ağızlardır. Ağızlar sayesinde Türkçenin hangi evrelerden geçtiğini, tarihî seyri içinde neleri barındırdığını, buna karşın nelerin unutulmaya yüz tuttuğunu görebiliriz. Ayrıca ağız çalışmaları Türkiye Türkçesi ile diğer Türk lehçeleri arasında karşılatırma yapma imkânı da vermektedir.

"Ağı" terimi, Büyük Türkçe Sözlük'te "aynı dil içinde ses, şekil, söz dizimi ve anlamca farklılıklar gösterebilen, belli yerleşim bölgelerine veya sinıflara özgü olan konuşma dili" olarak tanımlanır (http://www.tdk.gov.tr; 05. 07.2021).

Ağız kavramını Muharrem Ergin “bir şive içinde mevcut olan ve söyleyiş farklarına dayanan küçük kollar, bir memleketin çeşitli bölge ve şehirlerinin kelimeleri söyleyiş bakımından birbirinden ayrı olan konuşmaları" şeklinde tanımlarken (2012: 10), Zeynep Korkmaz "bir dilin veya bir lehçenin yazı diline oranla ve çoğunlukla ses, bazen de şekil, anlam ve söz varlığı bakımından birbirinden az çok ayrılan konuşma biçimleri" olarak tanımlamıştır (2003: 12).

Nurettin Demir ise ağzl; “aynı kökten geldiği üst sistem durumundaki bir standart dile bağlı, doğal olarak ortaya çıkmış; aile ve dost çevresinde, iş yerlerinde; okuryazarlığı az, bulunduğu bölgeden uzun süre ayrı kalmamış insanlarca sözlü iletişimde dilin başka türleri ile karşı karşıya gelme oranına göre değişen biçimde kullanılan, resmi ortamlarda kullanılmasından kaçınılan, yazılı bir gelenek oluşturamamış, iletişim alanı sınırlı, bağlı olduğu üst sistemden dilin her alanında karşıllklı anlaşmanın korunacağ 1 oranda ayrılabilen, prestiji standart dile göre daha az yerel konuşma biçimleridir." şeklinde tanimlar (2002: 114).

Türkiye'de ağız çalışmalarının tarihi oldukça eskidir. Türkiye Türkçesi ağızları üzerine bilinen en eski çalışma 1867'de Maksimov tarafından yapılan çalışmadır. Ağız çalışmalarının bu ilk dönemi yabancı araştırmacılar dönemi olarak da bilinmektedir. 1940 yılında Ahmet Caferoğlu tarafından Anadolu' nun çeşitli bölgelerinden yapılmaya başlanan derleme çalışmaları, ağız çalışmalarında yerli araştırmacılar döneminin de başlangıcı olarak kabul edilmektedir (Akar 2006: 38-39).

Yerli araştırmacılar tarafından yapılan ağız çalışmaları 1932 yılında Türk Dili Tetkik Cemiyetinin kurulmasıyla başlamıştır. 1940 yılından itibaren ise yerli araştırmacılar tarafından artık ağız çalışmaları yapılmaya başlanmıştır. Atatürk'ün talimatıyla kurulan Türk Dili Tetkik Cemiyetinin açılması dil bilincini doğurmuş ve dil çalışmalarına bu anlamda katkı sağlamıştır. Daha sonra ismi Türk Dil Kurumu olan kurumun ağızlarla ilgili ilk önemli çalışması, Anadolu'nun çeşitli bölgelerinden derlenmiş 150 binden fazla kelimenin yazıya aktarılması olmuştur. Bu kelimeler Türkiye'de Halk Ağzından Söz Derleme Dergisi'nde 1939-1949 yılları arasında yayımlanmıştır. Daha sonra 1952'de Türk Dil Kurumu tarafından ağızlardan kelime derleme çalışmalarına başlanmıştır ve sekiz yılda toplam 450 bin kelime derlenmiş ve bu kelimeler yazıya aktarılmıştır. Tüm bu eski ve yeni malzemeler birleştirilerek 1963-1982 yılları arasında “Derleme Sözlüğü" meydana getirilmiştir (Akar 2009: 6). 
Derleme Sözlüğü bugün, ağız sözlükçülüğünde en temel kaynak durumundadır. Bu kaynakta bugün zikredildiği gibi Türkiye Türkçesi ağızlarına ait oldukça zengin bir söz varlığı bulunmaktadır. Bununla birlikte ağızlarda yaşayıp da Derleme Sözlüğü’ne kaydedilmeyi bekleyen on binlerce söz varlığı bulunmaktadır (Buran 1996: 38). Derleme Sözlüğü'nün eksikliklerini tamamlamak maksadıyla zaman zaman bazı araştırmacılar tarafından "Derleme Sözlüğüne Katkılar" adıyla çeşitli yayınlar gerçekleştirilmiştir: (Karaörs 1994, Boz 1996, Buran 1996, Şanlı 1996, Kalay 1997, Gülensoy 1998, Şanlı 1999, Koraş 2002, Kalay 2004, Özgür 2004, Hazar 2007, Yıldız 2007, Biray 2009, Doğan 2009, Ersöz 2009, Öztürk 2009, Doğan 2010, Kamac1 2011, Karaman 2011, Teres 2011, Toker 2011, Eratalay ve Eratalay 2011, Doğan 2012, Tokatlı ve Erdem Nas 2012, Yeşilöz 2012, Acar 2013, Arslan 2013, Cankaya 2013, Güzel 2013a, Güzel 2013b, Özdarendeli 2013, Çiftçi 2014, Güven 2014, Tekin ve Cantürk 2014, Tokat 2014, Çavga 2015, Erdem Nas 2015, Özkaya 2015, Bulut 2016, Erdem Nas ve Parlar 2016, Erdoğan 2016, Erten ve Başkan 2016, Gülseren 2016, Küçükballı 2016a, Küçükballı 2016b, Metin 2016, Özek 2016, Yıldız ve Özsoy 2016, Çifci ve Sezer 2017, Demirci 2017a, Demirci 2017b, Demirtaş 2017, Eren ve Öztürk 2017, Tan ve Uğureli 2017, Uysal 2017, Arslan 2018, Erenoğlu Ataizi ve Sözer 2018, Bulut 2018, Çifci ve Sezer 2018, Çelik 2018, Direkçi 2018, Erdoğan 2018, Özden 2018a, Özden 2018b, Taş vd. 2018, Topal 2018, Turhan 2018, Uysal 2018, Atmaca ve Kaba 2019, Gökçe 2019, Güzel ve Kara 2019, Telli 2019, Telli ve Bulduk 2019, Bulut 2020, Büke 2020, Efe 2020, Kuşdemir 2020). $\mathrm{Bu}$ yayınlar vasitasıyla sözlüğün hem muhtevası genişleyecek hem de unutulmaya yüz tutmuş kavramların sözlüğe girmesi sağlanacaktır. Toplanan bu malzemeler ile Derleme Sözlüğü'nün genişletilmiş yeni basımının yapılması, Türkiye Türkçesi ağızlarındaki söz varlığını toplu olarak görmemizi sağlayacaktır.

\section{Sivas İli Ağızları}

Sivas ağzı ile ilgili ilk akademik çalışma Ahmet Caferoğlu'na aittir (Caferoğlu 1994). Ahmet Caferoğlu'ndan sonra Sivas ve ilçelerini ele alan çeşitli lisans tezleri, yüksek lisans tezleri, makaleler ve kitap çalışmaları yapılmıştır. ${ }^{1}$

Sivas ili ağızları Leylâ Karahan'ın hazırlamış olduğu Anadolu Ağızlarının Sınıflandırılması adlı eserde Batı Grubu ağıları içinde yer almıştır. Batı Grubu ağızlarını 9 alt gruba ayıran Karahan, Sivas ağzını VI. Grup içine dâhil etmiştir. Zara ilçesi ise bu grubun ikinci derecedeki alt grubu içinde sınıflandırılmıştır. Zara ilçesi ağzının bulunduğu ikinci derecedeki alt grupta Zile, Artova, Sivas merkez, Yıldızeli, Hafik ve Mesudiye ağıları bulunmaktadır (Karahan 2011: 167-171).

Zara ağzı ile ilgili tarafımızca bir yüksek lisans tezi hazırlanmıştır (Güven 2014). Bu çalışmaya başladığımızdan beri Zara ağzı ile ilgili çeşitli araştırma ve derleme

\footnotetext{
1 Yapılan çalışmalar için bk. Necati Demir ve Ülker Şen (2006). Sivas İli ve Yöresi Ağızları (Etnik Yapı-Dil Incelemesi-Metinler-Sözlük). Ankara: Gazi Kitabevi, s. XXXIX-XLII. Ayrıca bu eserde zikredilmeyen ve bu eser yayınlandıktan sonra yapılan yüksek lisans tezleri şunlardır: Şaban Doğan (2001). Sivas Merkez İlçe ve Köyleri A ğızları (Giriş-İnceleme-Metinler). Van: Yüzüncü Yıl Üniversitesi, SBE Yayımlanmamış Yüksek Lisans Tezi; Tülay Ayık Darıcı (2013). Şarkışla'nın Söz Varlığı. Sivas: Cumhuriyet Üniversitesi, SBE Yayımlanmamış Yüksek Lisans Tezi; Pınar Taş (2006). Şarkışla ve Yöresi Ağızları. Kayseri: Erciyes Üniversitesi SBE Yayımlanmamış Yüksek Lisans Tezi; Elif İçer (2010). Sivas İli Yıldızeli A ̆̆zı (İnceleme - Metinler - Sözlük). Edirne: Trakya Üniversitesi, SBE Yayımlanmamış Yüksek Lisans Tezi; Kadir Yılmaz (2011). Yıldızeli'nin Söz Varlı̆̆ı. Sivas: Cumhuriyet Üniversitesi, SBE Yayımlanmamış Yüksek Lisans Tezi; Leylâ Ökçura (2011). Sivas İli Kangal İlçe Merkezi Sözlüğü. Sivas: Cumhuriyet Üniversitesi, SBE Yayımlanmamış Yüksek Lisans Tezi; Ömer Güven (2014). Sivas İli Zara İlçesi A ̆gzı. İstanbul: İstanbul Üniversitesi, SBE Yayımlanmamış Yüksek Lisans Tezi; Eyyup Tanyıldız (2014). Hafik İlçe Merkezinin Kelime Hazinesi. Sivas: Cumhuriyet Üniversitesi, SBE Yayımlanmamış Yüksek Lisans Tezi; Zehra Öztürk (2014). Sivas İli Gürün İlçesi Merkez Köyleri A ğzı Sözlüğü. Sivas: Cumhuriyet Üniversitesi, SBE Yayımlanmamış Yüksek Lisans Tezi; Halil İbrahim Taşkıran (2021). Sivas Akıncılar A ̆gzı Karşılaştırmahı ve Tanıklı Sözlüğ̈̈̈. Sivas: Cumhuriyet Üniversitesi SBE Yayımlanmamış Yüksek Lisans Tezi.
}

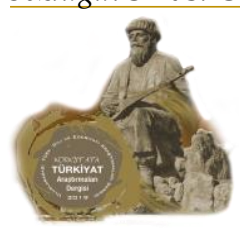


çalışmalarımız sürekli devam etmiştir. Bu kapsamda daha önce Zara (Sivas) A ğzından Derleme Sözlüğüne Katkılar (Güven 2014) adlı bir çalışma yapmıştık. Bu çalışma yayımlandıktan sonra tespit ettiğimiz dil malzemelerini bu çalışmamızda ele almaya çalıştık. Bu çalışmada daha önce yayımladığımız Zara (Sivas) A ğzından Derleme Sözlüğ̈̈ne Katkılar adlı çalışmada yer almayan sözcüklere yer verildi. Derlenen sözcükler değerlendirilirken;

\section{Zara ă̆zında yer alıp Derleme Sözlüğ̈̈̈nde bulunmayan sözcükler,}

Zara ă̆zında yer alıp Derleme Sözlüğ̈̈'ndeki anlamından farklı anlamı tespit edilen sözcükler, şeklinde iki temel başlık altında sınıflandırılmıştır. Bu başlıkların altında belirlenen söz varlığı; deyimler, beddualar, adlar, sıfatlar, zarflar, fiiller, ikilemeler ve ünlemler başlığı altında sözcük türü açısından sınıflandırılarak verilmiştir. Çalışmada, bu söz varlıklarının fonetik özelliklerini yansıtmak amacıyla transkripsiyon işaretleri kullanılmıştır. Yaptığımız bu çalışmayla asıl gayemiz Derleme Sözlüğ̈̈'nün yapılacak yeni baskılarına az da olsa bir katkı sunmaktır.

\section{Zara ağzında yer alıp Derleme Sözlï̈̆̈̈̈'nde bulunmayan sözcükler}

\subsection{Deyimler}

acın gabadayısı: Olduğu durumdan farklı görünmeye çalışanlar için söylenen alay yollu bir kınama ifadesi.

Adana leylā: Uzun boylu kimse.

ahur gór-: Hayvanların yemleme, sulama vs. bakımlarını yapmak.

ahlı yet-: Anlayabilecek yaşta olmak.

arhası ol-: Destek olmak, güvencesi olmak, dayanak olmak.

ārıyıp incinme-: Birisinden hiç kötülük görmemek, memnun olmak.

avara et-: Bir kimseyi işinden alıkoymak, oyalamak.

azap dur-: Bir aileye hizmetçi ve çoban olmak.

azap ver-: Çocuğu çoban olarak başka bir aileye vermek.

àzına bah-: Karşıdaki ne söylerse yapacak şekilde söyleyeceği şeyi beklemek.

āzına laf ver-: Yapılan bir davranış veya söylenen sözden dolayı başka kişilerin söz söyleme yetisi elde etmesi.

başdan girip ġısdan çıb̆-: Dil dökerek birini kandırmak, ona istediğini yaptırmak.

başı gótü ayru oyna-: Tutarsız davranmak.

başlı ġışlı yat-: Özellikle kalabalık ailelerde, bir yatakta birden fazla kişinin yatması gerektiğinden, döşeğin her iki ucuna da yastık konularak yatılması. Buna göre birinin ayağı diğerinin baş tarafında olurdu.

bazarlıh et-: Kız istendikten sonra alınacaklar konusunda aileler arasında yapılan görüşme.

bazarlıh gór-: Kız istendikten sonra alınacaklar konusunda aileler arasında yapılan görüşme.

behüzür et-: Rahatsız etmek, huzur vermemek.

bunnuh belası: Çaresizlik.

burnu gohu alma-: Dostunu düşmanını ayıramamak.

çarpana çal-: Ses çıkarmak, zil çalmak.

çöpük çal-: Alkışlamak.

dah dah delüsü et-: Harhangi bir şeyi söyleye söyleye ortaya düşürmek, çok dillendirmek.

dalı golu galma-: Dayanacak, güvenecek bir şeyi kalmamak.

daş gaya ol-: Bir hususta çok inat etmek.

datdirim yayla: Değersiz, yeğni kişiler için kullanılır.

Korkut Ata Türkiyat Araştırmaları Dergisi
Uluslararası Türk Dili ve Edebiyatı Araştırmaları Dergisi
The Journal of International Turkish Language \& Literature Research
Sayı 5/ Ağustos 2021


dayama ver-: Devrilmemesi için dayanak koymak.

deli deli ġonuş-: Saçma sapan konuşmak.

dene dut-: Tahılgillerin verimli olması ve ürünün bol olması için kullanılır.

depesüstü diklen-: İşleri bozulmak, düzeni alt üst olmak.

deremeti galma-: Dermanı kalmamak, dermanı kesilmek.

desinlere gèt-: Gösteriş yapmak için başkalarının söylediklerini uygulamak.

dımbıli dik-: Her şeyini kaybederek perişan olmak.

donah donan-: Süslenmek, farklı kiyafetler giyinmek.

dohuz daraḩda bezi ol-: Birçok işi veya ilişkisi olmak.

duman atdur-: Herhangi bir şeyi tüketmek, hiç bırakmamak.

ekís et-: Söz dokundurmak, iğnelemek.

eksúk gór-: Alışveriş yapmak, evin ihtiyaçlarını almak.

ele avuca düş-: Başkalarına muhtaç olmak, kendi ihtiyaçlarını karşılayamaz olmak.

eli dāme-: Fursat bulamamak, vakti olmamak.

elli ağızlı ol-: Yapılan bir işin güzel olması, yapanın içine sinmesi.

èlmini bil-: Bir işi iyi şekilde yapmak, işten anlamak.

kimse.

gaburgası galın: İnatçı, kimsenin sözünü dinlemeyip kendi dediğinde $1 s r a r c ı$ olan

galuh gal-: Evde kalmak, evlenme çağı geçmiş olmak.

ganı ağır: Ağır hareket eden, ağırcanlı.

ganın ġırmızı mı? "Senin ayrıcalığın ne" manasında kullanılan bir deyim.

gahış gah-: Kusurunu, ayıbını yüzüne vurmak.

garaltusu galh-: Yok olmak, ortadan kalkmak.

garaltusu gaybol-: Yok olmak, ortadan kalkmak.

garnı burhul-: Karnı şişmek.

ġırma ġırdır-: Tahıl ürünlerini değirmende öğüterek hayvanların yiyeceği hale getirmek.

ġııb goy-: Kapıyı aralıklı bırakmak.

ġızı öynüğü yırtılmış: Gereğinden çok yemek yiyen, doymak bilmeyen (kimse).

góbā düş-: Karın boşluğunun ağrıması.

gónünü gór-: Razı etmek, hoşnut olmasını sağlamak.

gót gadar: Çok küçük evler için kullanılır.

gótü yer górme-: Çok çalışmak, dinlenecek zaman bulamamak.

gótün geri gèt-: İşlerin gerilemesi, geriye gitmesi.

gótüynen kóy devir-: Sakar davranışlar sergilemek.

gózüne çal-: Gözüne ilişmek.

gún yüzü górme-: Rahat edememek, huzur bulamamak.

gurum gurum gurul-: Mağrur davranışlar sergilemek, çok böbürlenmek.

harazalı it gibi ısır-: Çok sinirli ve hırçın hareketlerde bulunmak.

hayhaya düş-: Telaşlanmak.

hẻç et-: Kullanılamaz hâle getirmek, ziyan etmek.

hersi çıh-: Sinirlenmek.

hezan gibi: İri yarı kimse.

hırlı dur-: Akıllı olmak, uslu durmak.

holasa holasa gonuş-: Daha çok komik ve nükteli konuşmak ve bu şekilde konuşarak etrafındakileri eğlendirmek.

hon et-: Çok 1srarc1 olmak, bezdirmek.

ilahası galma-: Darmadağın olmak, kullanılmayacak hale gelmek.

it üleşi gibi: Çok ağır. 
itiñ ayānı daşdan esirgeme-: Serbest bırakıp boş yere dolaşmasına engel olmamak, karşılaşabileceği zarara karışmamak.

itiñ olur: "Senin canın sağ olsun, sana feda olsun" anlamına bir söz.

ivini civini sor-: İnceden inceye araştırmak, soruşturmak, incelemek.

keyfinize bāde yoh: "Keyfiniz yerinde, neşeniz tam” anlamında bir deyim.

kór münkúr gel-: Yapılan iyiliği görmemek, inkâr etmek.

kúl hış ol-: Çok yorulmak.

kúrt çalıyor cingan oynuyor: Kalabalık ve çok ses olan ortamlar için kullanılan bir söz.

laviyet al-: Dalga geçmek, alay etmek.

leleğün et-: Alay etmek, birinin yaptıklarını yineleyerek eğlenmek.

mal gút- : Büyükbaş hayvanları otlatmak.

mızgı daral-: Morali bozulmak, sıkılmak, bunalmak daralmak.

muat ol-: Mukayyet olmak, göz kulak olmak, sahip çıkmak.

muhanete möhdaç ol-: Yabancı birine muhtaç olmak.

ohuyucu gibi dolan-: Çok gezmek, gereksiz yere dolaşmak.

öyün tayın bilme-: Vakitli vakitsiz bir şeyler yemek istemek, yemek zamanını beklememek.

ses etme-: Müdahale etmemek, karışmamak.

tanışlıb ver-: Kendisini tanitmak.

tavuk dider gibi dit-: Parçalanmamış, dağıtılmamış hiçbir şey bırakmamak.

tellal bağır-: Bir haber, bir istek vb.ni tellal aracılığıyla duyurmak, anons yapmak.

temek ver-: Samanlığa konulan samanları yerleştirmek, samanları ileri atmak.

unsuruh et-: Israrci olmak.

vesviye alma-: Önemsememek, değer vermemek.

kullanilır.

vırgel Anşanın inā: Bir eve, gerekli gereksiz, girenin çıkanın çok olması için

yaha yahaya gel-: Kavga etmek üzere olmak.

yedi deñiz çalḩalamış dışarı atmış: Sevilmeyen, bıkkınlık oluşturan kimseler için

kullanılan bir deyim.

yemek dók-: Ziyafet vermek, düğün gibi törenlerde gelenlere yemek ikram etmek. yerine yaḩış-: (Gelinler için) Gittiği eve uyum sağlamak.

yükúnü yüceye yı̆̆-: Kendini naza çekmek.

yüzünü yu-: Bir kişiyi hatalı olduğu hâlde kollamak, aklamaya çalışmak, savunmak. zopa at-: Dövmek, dayak atmak.

\subsection{Beddualar}

baba dā-: Başına bela gelmek.

bir sabunda bir suda yunasın: “Ölesin” anlamında beddua sözü.

çatın ayrılı gala: Genellikle çocuklara büyüklerin öfkelendiklerinde söyledikleri ve

"bacakların ayrila" anlaminda kullanilan bir beddua.

çerliyesice: "Ölesice" anlamında kullanılan beddua sözü.

garaltın gaybola: "Ölesin” anlaminda beddua sözü.

garaltun galha: "Ölesin" anlaminda beddua sözü.

mayan bata: "Soyun kuruya" anlaminda beddua sözü.

ocāñ kór gala: "Kimsen kalmasın" anlaminda beddua.

südúḲlūne daş dura: "İşeyemeyesin" anlamında kullanılan beddua.

südúḲlūn dutula: "İşeyemeyesin” anlaminda kullanılan beddua.

sürüm sürüm sürünesice: "Sürünesin, sıkıntı çekesin" anlamındaki beddua.

şişegalasıca: "Ölesice" anlamındaki beddua. 


\subsection{Sözcükler}

\subsubsection{Adlar}

abril beşi: 1-5 nisan günleri.

aporle: Hoparlör

baş yasdū: İki kişilik yastık.

bızlah: Sidik.

can yemā: Ölünün arkasından verilen yemek.

cankeş: Telaşlı.

cino: Çok haylaz ve uyanık çocuk.

çamdıgóz: Evlerin tavanındaki aydınlatma penceresi.

çar çaput: Paçavra, eski püskü bez veya giysi.

çetenyolah: Bacaya çıkılan yol.

türü.

çókelikli: Arasına çökelek, maydanoz ve yeşil soğan konularak yapılan bir bazlama

çul çaput: Paçavra, eski püskü bez veya giysi.

dalibik: Horozdaki tek olan ibik.

dohuz aylık: Futbol şeklinde bir ebenin kaleye geçtiği ve diğerlerinin sadece topa bir kez dokunma hakkının olduğu ve 9 gol yiyenin elendiği bir oyun.

ekimay1: Sonbahar.

eKsşilaş: Yarma, kurutulmuş kaysı, üzüm, pekmez, nohut vb. karışımından yapılan bir tür yemek.

ganatlu: İki kanatlı kapıları olan garaj.

garacaharman: Ekin başaklarını yakarak yapılan kavurga, firik.

garagura sandū: Gereksiz eşyaların konulduğu sandık.

gayfirenkli: Kahverengi.

gendügelen: Kendiliğinden büyüyen ağaç.

gıdiboòu: Vez.

ġıranta: Saç ve sakalı ağarmış erkek.

ġırın başı: Ağaç ve yeşillik olmayan bölge.

ġıs guzusu: Nisan ayından önce doğan kuzuya denir.

ġş tohllusu: Nisan ayından önce doğan kuzuya denir.

gupbe: Köy evlerinin bacasında bırakılan aydınlanma deliği.

gülibik: Tavuklardaki geniş olan ibik.

iki guplu: İki kulplu bir kazan türü.

karamondo: Siyah renkli okul önlügüü.

kero: Eşek.

kesme hamur çorbası: Mercimekli ve hamurlu çorba.

keygür: Süzgeç.

kóskúrā: Ateşin közünü almaya yarayan kürek.

kústüm: Çift kişilik yastık.

kúşgúr: Küçük tezek parçası.

lotgomer: Mont.

muşma: Yumruk.

osmannılıh̆: (Kadın için) Dirayetli olma, sözünü geçirme, erkekçe davranış sergileme.

peşli entere: Kadınların şalvar üzerine giydiği üç parçalı uzun kadın elbisesi pine mıhı: En küçük çivi.

pire torbası: Köpeklere, özellikle uyuz olanlara, verilmiş genel lâkap.

sahoğul: Karamuktan yapılmış ahır süpürgesi. 
sırıntırah: Etin sinirli kısmı.

sinenbicilik: Saklambaç oyunu.

tarın başı: Yüksekçe yer.

tayın: Öğün.

unnama: Küçük parçalar halinde doğranan karalahananın mısır unu ile yapılan yemeği.

yamak: Birisine yağ yakan, yaranmaya çalışan.

yasduluh: Yatsıdan sonra yenilen yemek.

yaylım vahdı: Havaların ısınmasıyla beraber hayvanların otlamaya başladıkları dönem.

yaz başı: Mart ayı.

\subsubsection{Sifatlar}

baldırı gıcıh: Yarı çıplak gezen kimse.

boğazı büyük: Çok yemek yiyen.

ciğerci: Akrabasına düşkün olan.

cöherli: Cesur, gözü pek.

çıtmalı: 1. Huysuzluk yapan büyükbaş hayvan. 2. Kavga çıkaran.

çorlu dingiş: Aşırı zayıf.

daąmsüz: Münasebetsiz.

dırcikli: Zıplayan, yerinde duramayan.

dilferzā: Çok konuşan, herkese laf yetiştiren kimse, dil ebesi.

follan: Bol.

fuhare: Fukara.

ġyı kóy: Kenar köy, başka köy.

górök: Son.

hamdabaş: Başına buyruk, söz dinlemeyen.

hecim: 1 . Güçlü. 2 Geçimsiz.

hecin devesi: Uzun boylu kimse.

heyheyli: Gel git akıllı.

hınım: Sesleri genizden çıkararak konuşan (kimse).

hötürüklü: Küfürbaz.

hulik: Sağır.

1hballı: Talihli.

içerli: Her şeye üzülen ve alınganlık gösteren (kimse).

işli: Çalışkan, becerikli, elinden iyi iş gelen.

kerhanacı: Özellikle çocuklara şaka yollu iğneleme sözü.

kirşef: Kötü huylu kişi.

kizni: Gözü aç, doymak bilmeyen.

lolo: Beceriksiz.

mıymı: Sünepe, uyuşuk, ağır hareket eden.

nallı: Asi, başına buyruk, kimseyi umursamayan.

nizalı: 1. Asık suratlı. 2. Ağlamaklı, ağlak. 3. Mahkemelik olan.

sadırlı: Sidikli.

sahsahlı: Kirli, pasaklı (kadın).

sapa yer: Tenha, issız yer.

satlıh ġı: Evlenme çağına gelmiş kız.

sose: Aptal, akilsiz.

sölpüklü: Seli ve salyası akan.

şefil: 1. Salya, tükürük. 2. Buğdayın kaynarken çıkan kıvamlı sıvısı. 
şikârlı: 1. Değerli, önemli, kıymetli. 2. Nazlı.

tiftikli: Uzun saçlı.

yazucu: Düğündeki çeyiz vb. eşyaları yazan kimse.

yedi yabancı: Çok yabanc1.

zotdiri: Serseri, sersem, boş gezen.

\subsubsection{Zarflar}

ağırdan: Yavaşça.

bi goşam Bir tutam, azıcık.

hayheşem: Alelacele, telaşla.

hokikten: Bedavadan.

irelüğün: Dünden önceki gün.

neçe sōna: Çok sonra.

sallamseyip: Başıboş gezme.

1.3.4. Fiiller

acizlen-: Sızlanmak, yakınmak.

amel ol-: İshal olmak.

asbap yu-: Çamaşır yıkamak.

azetle-: Ağırlamak, hürmet ve ikramda bulunmak.

büz-: Bir şey örerken yanlış yapılan kısmı onarmak, düzeltmek.

çöpük çal-: Alkışlamak.

değişil-: Değişmek, farklılaşmak.

dıḩdala-: Sıkıştırmak.

dirlik verme-: Huzur vermemek.

etini bük-: Çimdiklemek.

fosulla-: Bir işi baştan savarak yapmak, geçiştirmek.

gahirlen-: Üzülmek, içerlemek, kederşenmek.

garelle-: Tahmini, el yordamı ve göz kararıyla ölçmek.

garipse-: Özlemek.

gaydelen-: Müziğe kendini kaptırmak, sağa sola sallanmak.

gevret-: Ateşin üstünde isıtıp çıtır çıtır hâle getirmek.

gisgala-: Sıkıştırmak.

ġssg̀1 ver-: Gözünü korkutmak.

gohna-: Kavga etmek.

gúnned-: Güneşlendirmek.

guyul-: (Sığırlar için) Serbest bırakılmak, dağılmak.

hayiplen-: Şaşırmak.

hıncala-: Pancar vb. bitkileri küçük parçalara ayırmak.

kellelen-: Soğan ve sarımsağın baş tutması.

kikile-: Kısık sesle gülmek.

kórcülen-: Ateşin tutuştuktan sonra tekrar sönmesi.

loğuzla-: Sakinleştirmek, gönül almak.

löpürdet-: İştahla yemek.

mehelse-: Değer vermek, önem vermek, önemli saymak.

mehmanlaş-: Sersemlemek, uyuşmak.

mımışle-: Giyinip süslenip bir köşeye çekilmek, iş yapmamak.

poçut-: Kaçmak.

sosurda-: Söylenmek, homurdanmak, gönülsüz iş görmek.

süflen-: Zaman geçirmek, oyalanmak.

şarlat-: Küçük çocukların gece yatağı ıslatmaları. 
şoşalt-: Abartmak.

tayınla-: Bir işi her zaman ayni vakitte yapmak.

tığlandur-: Yığmak.

tıb̆ıla-: Ateşte az tutmak, kısa bir süre kaynatmak.

tī savur-: Harmanda, tahılları samandan ve çöpten ayırmak için havaya doğru serpmek.

tumbul-: Suya batmak, dalmak.

uylat-: Bezdirme derecesinde israr etmek.

zerzele-: Kapıyı kilitlemek.

\subsection{5. İkilemeler}

acı zulum: Zor şartlarda, kısıtlı imkânlarda.

ahrih pihrih: Balgam.

aş keş: Yemek.

bel bihın: Sirt bel.

dar diḩız: Sıkış tıkış.

dóklüm döşek: Darmadağınık.

eksi beki: Az kullanılmış çamaşır, elbise veya eşya.

gam gasefet: Kasavet, üzüntü, tasa, kayg1.

gavum hisım: Akrabalar.

gildırı gıcıh: Önemsiz ayrıntı.

ġyıda gulahda: Kenarda, köşede.

goru gonşu: Bütün komşular, birbirine yakın yerde oturan kimseler.

gúlgúbür: Evin süpürülmesiyle ortaya çıkan toz birikintisi.

kúnde kúnde: Her gün.

perme perişan: Çok perişan bir hâlde.

sallam seyip: Başıboş.

tarla tump: Tarla marla anlaminda ikileme.

uşaḩ devşek: Çoluk çocuk.

yarlu yahuşuhlu: Düzenli tertipli.

2. Zara ağzında yer alıp Derleme Sözlü̈̆̈̈̈'ndeki anlamından farklı anlamı tespit edilen sözcükler

\subsection{Deyimler}

ağız ĕg-: Minnet etmek. ( $k r s ̧$. DS I, 96)

gadana gibi: İri yapılı. (krş. DS III, 1889)

yüz dutnā: Daha önceden yardım edilen birinden yardım istemeye yüzü olmak. ( $k r s ̧$. DS VI, 4829)

\subsection{Beddualar}

başını bārını ye-: Ölmek anlamında beddua olarak kullanılır. (krş. DS II, 560)

\subsection{Sözcükler}

\subsubsection{Adlar}

áğme: Tandırın üzerine yer alan, dumanın dağılmasını önleyerek bacadan çıkmasını sağlayan bölüm. ( $k r s ̧$. DS III, 1681)

bozalah: Beyaza yakın bir renk, boz renge çalan. ( $k r s ̧$. DS I, 748)

duzsuzluh: Tatsız şakalar yapma. (krş. DS II, 1615)

fino: Küçük köpek, köpek yavrusu. (krş. DS III, 1868) 
garaltı: Siyahlık, karartı. (krş. DS III, 2650)

gasafet: Üzüntü, tasa. (krş. DS III, 1931)

gever: Tarlanaın sert olan toprağına denilir. ( $k r s ̧$. DS III, 2009)

gurik: Kulakları küçük. (krş. DS III, 2198)

hah: Yapılan iş karşılığında alınan ücret. (krş. DS III, 2252)

keben: Yolu kötü olan yer. ( $k r s ̧$. DS IV, 2715)

kúsgü: Taş kaldırmada kullanılan basit kaldıraç. (krş. DS IV, 3014)

ürüsüm: Yaratılış özelliği, tıynet. (krş. DS VI, 4074)

\subsubsection{Sifatlar}

cinibiz: Kurnaz, üçkâğıtçı. (krş. DS II, 980)

çelpeşük: 1. Zor söylenen kelime ya da söz. 2. Sarhoş, düzgün yürüyemeyen kimse.

(krş. DS II, 1126)

çepil: Çokbilmiş. (krş. DS II, 1143)

dındık: İşi titizlikle ve ağır ağır yapan. (krş. DS II, 1462)

dutgun: Her şeyden çekinen, ürkek, tutuk (kimse). (krş. DS II, 1612)

duzsuz: Tatsız şakalar yapan kişi. (krş. DS II, 1615)

ehvan: Hafif. (krş. DS III, 1691)

eserüklü: Deli, delimsirek ( $k r s ̧$. DS III, 1783)

filik: Beyaz keçi. (krş. DS III, 1865)

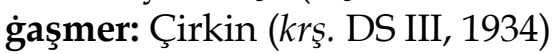

gereme: Kuçak dolusu. (krş. DS III, 1997)

gicimüklü: Kızışmış. (krş. DS III, 2072)

habu: Abla. (krş. DS III, 2247)

holasa: Şakacı, güleryüzlü. ( $k r s ̧$. DS III, 2396)

lele: Kurnazlığa aklı ermeyen, kolaylıkla aldatılabilen. (krş. DS IV, 3072)

saçaḩlı: Kirli, pasaklı, pis. (krş. DS V, 3510)

zırıl: 1. Uzun boylu ve iri yapılı kişi. 2. Eşek. (krş. DS VI, 4379)

\subsubsection{Zarflar}

çaşut: Çok gezen. (krş. DS II, 1085)

sip: Çabuk, hızlı. (krş. DS V, 3646)

\subsubsection{Fiiller}

afkala-: Öfkeyle söylenmek, kızmak, bağırmak. (krş. DS I, 73)

ahdar-: Sacın üzerindeki yufkayı çevirmek. (krş. DS I, 128)

dızıla-: (Çocuklar için) Ağlamak. (krş. DS II, 1477)

fısınla-: Dumanın geri tepmesi. ( $k r s ̧$. DS III, 1858)

gah-: Toslamak, vurmak (inek ve öküz için). (krş. DS III, 1895)

gaypit-: Damlatmak. (krş. DS III, 1949)

goh-: Küsmek, gücenmek. (krş. DS III, 2096)

heyikle-: Boş boş dolanmak, gereksiz yere gezintiye çıkmak. (krş. DS III, 2353)

kıpçın-: Bir şeyi elde etmeye çalışmak, o yönde hareket etmek. ( $k r s ̧$. DS IV, 2813)

pört-: Elinden kurtulmak, kaçmak. (krş. DS V, 3482)

sürgúle-: Kilitlemek. (krş. DS V, 3722)

yalla-: Kötü bir işte çıkar sağlayacağı kişiyi beslemek. (krş. DS VI, 4149)

\subsection{5. Ünlemler}

hoho: Büyükbaş hayvanları çağırma ünlemi. (krş. DS III, 2394) 


\section{Sonuç}

Türkçenin çok önemli fonetik ve morfolojik özellikleri ile söz varlığının muhafaza edildiği ağızlarla ile ilgili çalışmaların son yıllarda ivme kazanması dilimiz açısından dikkate değer gelişmelerden biridir. Özellikle yapılan derleme faaliyetleri ve söz varlı̆̆ını tespite yönelik çalışmalar, unutulmaya yüz tutmuş pek çok verinin kayıt altına alınmasını sağlanmaktadır. Başta teknolojik gelişmeler olmak üzere çeşitli nedenlerle ağızlarda yer alan pek çok söz varlığı kullanımdan düşmekte ve yok olma tehlikesiyle karşı karşıya gelmektedir. Bu sebeple ağızlarda yer alan söz varlıklarının tespit edilerek kayıt altına alınması ağız çalışmaları arasında önemli bir yer tutmaktadır. Bu maksatla son yıllarda "Derleme Sözlügüüne Katkılar" adını taşıyan pek çok çalışma yapılmıştır. Bu çalışmalarda belgelenen söz varlığı unsurlarının Derleme Sözlüğü'nün yapılacak yeni baskılarına eklenmesi ile sözlüğün zenginleşmesi ve Türkiye Türkçesi ağızlarındaki söz varlığını en geniş kapsamlı temsil etmesi sağlanacaktır. Nitekim çeşitli araştırmacılar tarafından Derleme Sözlüğ̈̈̈'nün Anadolu'da varlığını sürdüren ağızların zenginliğini tam olarak yansıtamadığı dile getirilmiştir (Gülensoy 1999: 20).

Zara (Sivas) Ağzından Derleme Sözlüğüne Katkılar II adlı bu kısa çalışmamızı Zara ağzında yer alıp Derleme Sözlüğ̈̈'nde bulunmayan sözcükler ve Zara ağzında yer alıp Derleme Sözlüğ̈̈'ndeki anlamından farklı anlamı tespit edilen sözcükler şeklinde iki başlık altında ele aldık. Çalışmada Zara ağzında yer alıp Derleme Sözlüğü'nde yer almayan 101 deyim, 12 beddua, 52 ad, 42 sıfat, 7 zarf, 43 fiil ve 19 ikileme; Zara ağzında yer alıp Derleme Sözlüğü'ndeki anlamından farklı anlam taşıyan 3 deyim, 1 beddua, 12 ad, 17 sıfat, 2 zarf, 12 fiil ve 1 ünlem tespit edilmiştir.

Elbette ki Zara ağzının söz varlığı bu kadarla sınırlı değildir. Yapılacak yeni derlemeler neticesinde yeni yeni kelimelerin ortaya çıkacağı kesindir.

\section{Kaynakça}

Acar, Kenan (2013). Türkiye Türkçesi Ağızlar Sözlüğüne Kandıra Ağzından Katkılar. Turkish Studies International Periodical For The Languages, 8(9), 375-386.

Akar, Ali (2009). Ağız Sözlükleri: Yöntem ve Sorunlar -I-. Turkish Studies International Periodical For The Languages, 4(4), 1-11.

Arslan, Büşra (2013). Çatpınar (Doğanşar/Sivas) Ağzından Derleme Sözlüğü'ne Katkılar. Dil ve Edebiyat Araştırmaları, 8, 97-102.

Arslan, Döne (2018). Eğirdir ve Yöresi Ağızlarından Derleme Sözlüğüne Katkılar. TÜRÜK Uluslararası Dil, Edebiyat ve Halkbilimi Araştırmaları Dergisi, 6(15), 358-363.

Atmaca, Emine ve Kaba, Oğuzhan (2019). Alanya, (Antalya) Ağzından Derleme Sözlüğ̈̈̈ne Katkılar. Doğumunun 120. Yılında Prof. Dr. Ahmet Caferoğlu Hatıra Kitabı (Ed. Fikret Turan-Özcan Tabaklar), İstanbul: Şenyıldız Matbaacılık, 205-234.

Ayık Darıcı, Tülay (2013). Şarkışla'nın Söz Varlığı. Yüksek Lisans Tezi. Sivas: Cumhuriyet Üniv.

Biray, Nergis (2009). Denizli Ağzından Derleme Sözlüğü'ne Katkılar. Turkish Studies International Periodical For The Languages, 4(8), 747-776.

Boz, Erdoğan (1996). Çüngüş ve Çermik Yöresi Ağzından Derleme Sözlüğüne Katkılar. Milli Folklor, 4, 112-113.

Bulut, Serdar (2016). Dereli, Eynesil ve Görele İlçeleri Ağızlarından Derleme Sözlüğü'ne Katkılar. 1. Uluslararası Sosyal Bilimler Sempozyumu Özet Kitapçı̆̆ı, 366.

Korkut Ata Türkiyat Araştırmaları Dergisi
Uluslararası Türk Dili ve Edebiyatı Araştırmaları Dergisi
The Journal of International Turkish Language E Literature Research
Sayı 5/ Ağustos 2021


Bulut, Serdar (2020). Alanya (Antalya) Ağzından “Derleme Sözlüğü"ne Katkılar. Akademik Sosyal Araştırmalar Dergisi, 8(111), 117-144.

Bulut, Serdar (2017). Serik (Antalya) Yörükleri Ağzından “Derleme Sözlüğü”ne Katkılar. Route Educational and Social Science Journal Volume, 4(5), 127-141.

Bulut, Serdar (2018). Gümüşhane İli ve Yöresi Ağızlarından Derleme Sözlüğ̈ü'ne Katkılar. Karadeniz Araştırmaları, XV(57), 171-190.

Buran, Ahmet (1996). Derleme Sözlüğüne Katkılar. Türk Dili, 535, 38-43.

Büke, Himmet (2020). Denizli Ağzından Derleme Sözlüğüne Katkılar. SDÜ Fen-Edebiyat Fakültesi Sosyal Bilimler Dergisi, 50, 131-148.

Caferoğlu, Ahmet (1994). Sivas ve Tokat Illeri Ağızlarından Toplamalar. Ankara: TDK Yayınları.

Cankaya, Mahir (2013). Erzincan Ağzından Derleme Sözlüğü'ne Katkılar. Turkish Studies International Periodical For The Languages, 8(9), 899-910.

Çavga, Uğur (2015). Belkaya (Konya Ereğli) Ağzından Derleme Sözlüğüne Katkılar. International Journal Of Languages' Education And Teaching, 2198-4999, 2669- 2689.

Çelik, Anıl (2018). Yalova İli Yerli Ağzından Türkiye Türkçesi Ağıları Sözlüğü'ne Katkılar. Avrasya Uluslararası Araştırmalar Dergisi, 6(13), 512-543.

Çifci, Musa ve Sezer, Önder (2017). Derleme Sözlüğüne Katkılar (Emirdağ/Burunarkaç Köyü). Turkish Studies International Periodical For The Languages, 12(15), 211-232.

Çifci, Musa ve Sezer, Önder (2018). Derleme Sözlügüne Katkılar (Emirdağ/Burunarkaç Köyü). Turkish Studies International Periodical For The Languages, 13(28), 241-264.

Çiftçi, Fethullah (2014). Bitlis Merkez A ğzından Derleme Sözlüğüne Katkılar. Muş Alparslan Üniv. Sosyal Bilimler Dergisi, 2(2), 261-272.

Demir, Necati ve Şen, Ülker (2006). Sivas İli ve Yöresi Ağızları (Etnik Yapı-Dil İncelemesiMetinler-Sözlük), Ankara: Gazi Kitabevi.

Demir, Nurettin (2002). Ağız Terimi Üzerine. Türkbilig, 4, 105-116.

Demirci, Metin (2017a). Derleme Sözlüğü'ne Osmaniye, Düziçi Ağzından Katkılar-I, Uluslararası Türkçe Edebiyat Kültür Eğitim Dergisi (TEKE), 6(3), 1360-1383.

Demirci, Metin (2017b). Osmaniye, Düziçi Ağzından Derleme Sözlüğü'ne Katkılar-2. KMÜ Sosyal ve Ekonomik Araştırmalar Dergisi, 19(33), 36-44.

Demirtaş, Ahmet (2017). Osmaniye Ağzından Derleme Sözlüğüne Katkılar, IX. Uluslararası Dünya Dili Türkçe Sempozyumu, 02-04 Kasım 2017, İnönü Üniv., Malatya, 196-209.

Direkci, Bekir (2018). Derebucak (Merkez) A ğzından Derleme Sözlüğüne Katkılar. Turkish Studies International Periodical For The Languages, 13(20), 383-402.

Doğan, Muammer (2009). Aksaray Ağzından Derleme Sözlüğüne Katkılar-1. Turkish Studies International Periodical For The Languages, 4(4), 236-249.

Doğan, Muammer (2010). Aksaray Ağzından Derleme Sözlüğüne Katkılar-2. Turkish Studies International Periodical For The Languages, 5(1), 294-312.

Doğan, Muammer (2012). Aksaray Ağzından Derleme Sözlüğüne Katkılar-3. Diyalektolog Ulusal Sosyal Bilimler Dergisi, 4, 9-21. 
Doğan, Şaban (2001). Sivas Merkez İlçe ve Köyleri Ağızları (Giriş-İnceleme-Metinler). Van: Yüzüncü Yıl Üniv. SBE Yayımlanmamış Yüksek Lisans Tezi.

Efe, Kürşat (2020). Ankara Güdül Ağzından Derleme Sözlüğüne Katkılar, Sosyal Bilimler Dergisi / The Journal of Social Science, 7(49), 786-827.

Eratalay, Sevda ve Eratalay, Süleyman (2012). Alaşehir Ağzından Derleme Sözlüğüne Katk1lar. IV. Uluslararası Dünya Dili Türkçe Sempozyumu, 1. Cilt, 353-364.

Erdem Nas, Gönül (2015). Anamur Ağzından Derleme Sözlüğü'ne Katkılar 2. Journal of Turkish Language and Literature, 1(1), (1-8).

Erdem Nas, Gönül ve Parlar, Zahide (2016). Bartın Ağzından Derleme Sözlüğ̈ü'ne Katkılar. Diyalektolog Ulusal Hakemli Sosyal Bilimler Dergisi, 13, 50-59.

Erdoğan, Songül (2016). Niğde Yöresi Ağzından Derleme Sözlüğü'ne Katkılar-1. Journal of Türklük Bilimi Araştırmaları, 40, 69-82.

Erdoğan, Songül (2018). Türk Oyaları Kataloğu'ndan Derleme Sözlüğ̈̈̈'ne Katkılar. Turkish Studies International Periodical For The Languages, 13(20), 437-450.

Eren, Abdullah ve Öztürk, Abdulkadir (2017). Yukarıkızılen Köyü Ağzından Derleme Sözlüğü'ne Katkılar. Ordu Üniv. Sosyal Bilimler Araştırmaları Dergisi, 7(3), 413-421.

Erenoğlu Ataizi, Dilek ve Sözer, Burak (2018). Kadınhanı Ağzı'ndan Derleme Sözlüğü'ne Katkılar. МСВÜ Sosyal Bilimler Dergisi, 16(1), 579-592.

Ergin, Muharrem (2012). Türk Dil Bilgisi, İstanbul: Bayrak Basım Yayın-Tanıtım.

Ersöz, Serpil (2009). Nazilli (Aydın) Ağzından Derleme Sözlüğü'ne Katkılar. Türk Dünyası İncelemeleri Dergisi, 2, 37-62.

Erten, Münir ve Başkan, Ahmet (2016). Bismil Ağzından Derleme Sözlüğü'ne Katkılar. CÜ Sosyal Bilimler Dergisi, 40(2), 67-77.

Gökçe, Hüseyin (2019). Bursa Dağ Yöresinden (Keles ve Orhaneli İlçelerinden) Derleme Sözlüğ̈̈'ne Katkılar. UÜ Fen-Edebiyat Fakültesi Sosyal Bilimler Dergisi, 20(36), 79-100.

Gülensoy, Tuncer (1998). Anadolu Ağızlarından Derleme Sözlügüune Katkılar. Türk Dili, $553,14-17$.

Gülensoy, Tuncer (1999). Ağız Araştırmalarının Bugünkü Durumu. Ağız Araştırmaları Bilgi Şöleni (9 Mayıs 1997), Ankara: TDK Yayınları.

Gülseren, Cemil (2016). Malatya'dan Derleme Sözlüğü'ne Katkılar. Diyalektolog Ulusal Sosyal Bilimler Dergisi, 12, 47-55.

Güven, Ömer (2014). Sivas İli Zara İlçesi Ağzı, İstanbul: İstanbul Üniv., SBE Yayımlanmamış Yüksek Lisans Tezi.

Güven, Ömer (2014). Zara (Sivas) Ağzından Derleme Sözlügüüne Katkılar, İstanbul Üniv., Edebiyat Fakültesi Türk Dili ve Edebiyatı Dergisi, LI, 63-78.

Güzel, Ferdi (2013a). Şahsuvar (Elazığ) Ağzından Derleme Sözlüğü'ne Katkılar. Türk Dili, $728,68-80$.

Güzel, Ferdi (2013b). Şahsuvar (Elazığ) Ağzından Derleme Sözlüğü'ne Katkılar 2. Diyalektolog Ulusal Sosyal Bilimler Dergisi, 6, 15-33.

Güzel, Ferdi ve Kara, Kürşat (2019). Artvin İli, Şavşat İlçesi, Yukarı Koyunlu (Süles) Köyünden Derleme Sözlüğü'ne Katkılar. AÇÜ Uluslararası Sosyal Bilimler Dergisi, $5(1), 37-52$.

Korkut Ata Türkiyat Araştırmaları Dergisi
Uluslararası Türk Dili ve Edebiyatı Araştırmaları Dergisi
The Journal of International Turkish Language E Literature Research
Sayı 5/ Ağustos 2021


Hazar, Mehmet (2007). Nevşehir Folkloru'ndan Derleme Sözlüğü'ne Katkılar. Türk Dili, $669,580-584$.

İçer, Elif (2010). İli Yıldızeli A ğzı (İnceleme - Metinler - Sözlük). Edirne: Trakya Üniv., SBE Yayımlanmamış Yüksek Lisans Tezi.

Kalay, Emin (1997). Edirne İli Ağılarından Derleme Sözlügüune Katkılar I. Türk Dili, 547, 25-33.

Kalay, Emin (2004). Edirne İli Ağızlarından Derleme Sözlüğüne Katkılar II. Türk Dili, 633, 250-259.

Kamacı, Duygu (2011). Erzurum Yöresi Ağızlarından Derleme Sözlüğüne Katkılar. Akdeniz İnsani Bilimler Dergisi, 1(1), 158-164.

Karahan, Leyla (1996). Anadolu Ağızlarının Sinıflandırılması. Ankara: TDK Yayınları.

Karaman, Ahmet (2011). Sandıklı Ağzından Derleme Sözlüğü'ne Katkılar. Dil ve Edebiyat Araştırmalarn Dergisi, 2(3), 273-286.

Karaörs, Metin (1994). Derleme Sözlüğüne Katkılar Kayseri, Isparta, Adana İllerinden Derlemeler. Türk Dili, 505, 65-67.

Koraş, Hikmet (2002). Derleme Sözlügüüne İlaveler. Türklük Bilimi Araştırmaları, 12, 171- 209.

Korkmaz, Zeynep (2003). Gramer Terimleri Sözlüğü. Ankara: TDK Yayınları.

Kuşdemir, Ayeşegül (2020). Tokat ve Yöresi Ağzından Derleme Sözlüğü’ne Katkılar I. The Journal of Turkic Language and Literature Surveys (TULLIS) 5(1), 39-55.

Küçükballı, Fatih Numan (2016a). "Gazipaşa Dillere Destan” Adlı Eserden “Derleme Sözlüğü"ne Katkılar. Selçuk Üniv. Türkiyat Araştırmalan Dergisi, 37, 309-370.

Küçükballı, Fatih Numan (2016b). Bozkır (Konya) Ağzından Derleme Sözlüğ̈̈'ne Katkılar, Uluslararası Sempozyum: Geçmişten Günümüze Bozkır, 06-08 Mayıs 2016, 643-658.

Metin, Beyazıt Bilge (2016). Geydoğan Ağzından Derleme Sözlüğüne Katkılar. Dede Korkut Uluslararası Türk Dili ve Edebiyatı Araştırmaları Dergisi, 5(11), 78-87.

Ökruca, Leylâ (2011). Sivas İli Kangal İlçe Merkezi Sözlüğü. Sivas: Cumhuriyet Üniv. SBE Yayımlanmamış Yüksek Lisans Tezi.

Özdarendeli, Nursel (2013). Velimeşe Ağzından Derleme Sözlüğüne Katkılar, Türkiyat Araştırmaları, 34, s. 57-79.

Özden, Muharrem (2018a). Bilecik Ağzından Derleme Sözlüğüne Katkılar. Avrasya Uluslararası Araştırmalar Dergisi, 5(11), 273-315.

Özden, Muharrem (2018b). Gümülcine Ağzından Derleme Sözlüğüne Katkılar. Diyalektolog Ulusal Hakemli Sosyal Bilimler Dergisi, 17, 199-249.

Özek, Fatih (2016). Arapgir Ağzından Derleme Sözlüğü'ne Katkılar. 1. Uluslararası Sosyal Bilimler Sempozyumu Özet Kitapçı̆̆ı, 43.

Özgür, Can (2004). Eskişehir Yöresi Ağızlarından Derleme Sözlüğü'ne Katkılar. TDAY Belleten, 2004/1, 93-99.

Özkaya, Hakkı (2015). Kırklareli İli Ağızlarından Derleme Sözlüğüne Katkılar. Rumeli'de Dil ve Edebiyat Araştırmaları Dergisi, 2, 33-39.

Öztürk, Erol (2009). Mersin Yörüklerinden Derleme Sözlüğü'ne Katkılar. Türk Dili, 689, 405411. 
Öztürk, Zehra (2014). Sivas İli Gürün İlçesi Merkez Köyleri A ğzı Sözlü̆̆ü. Sivas: Cumhuriyet Üniv., SBE Yayımlanmamış Yüksek Lisans Tezi.

Şanl1, Cevcet (1996). Kırklareli, Erzurum ve Artvin İllerimizden Derleme Sözlüğüne Katkılar. Türk Dili, 552, 542-547.

Şanlı, Cevdet (1999). Anadolu ve Rumeli Ağızlarından Derleme Sözlüğüne Katkılar. Türk Dili, 572, 670-680.

Tan, Ali ve Uğureli, Ayşe (2017). Kesikkeli Köyünden Derleme Sözlüğü'ne Katkılar. Diyalektolog Ulusal Sosyal Bilimler Dergisi, 16, 223-239.

Tanyıldız, Eyyup (2014). Hafik İlçe Merkezinin Kelime Hazinesi. Sivas: Cumhuriyet Üniv. SBE Yayımlanmamış Yüksek Lisans Tezi.

Taş N. Fahri vd. (2018). Erzincan Refahiye Ağzından Derleme Sözlüğü'ne Katkılar, TüRÜK Uluslararası Dil, Edebiyat ve Halkbilimi Araştırmalan Dergisi, 6(12), 61-66.

Taş, Pınar (2006). Şarkışla ve Yöresi Ağızları. Kayseri: Erciyes Üniv. SBE Yayımlanmamış Yüksek Lisans Tezi.

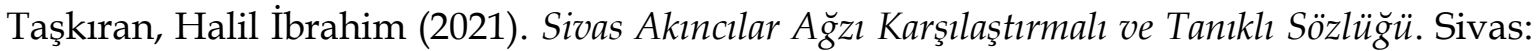
Cumhuriyet Üniv. SBE Yayımlanmamış Yüksek Lisans Tezi.

Tekin, Feridun ve Cantürk, Samet (2014). Giresun ve Yöresi Ağızlarından Derleme Sözlüğ̈̈'ne Katkılar. Diyalektolog Ulusal Hakemli Sosyal Bilimler Dergisi, 9, 33-46.

Telli, Burak (2019). Hatay Ağzından Derleme Sözlüğü'ne Katkılar. Tarih Okulu Dergisi (TOD) 12(XXXVIII), 664-693.

Telli, Burak ve Bulduk, Türker Barış (2019). Adıyaman İli ve Yöresi Ağılarından Derleme Sözlüğ̈̈'ne Katkılar: Fiil. Hikmet-Akademik Edebiyat Dergisi, 5(10), 98-115.

Teres, Ersin (2011). Söğüt (Bilecik) Ağzından Derleme Sözlüğüne Katkılar. Folklor/Edebiyat, 17(65), 19-26.

Tokat, Feyza (2014). Çavdır Ağzından Derleme Sözlüğü'ne Katkılar. Uluslararası Türkçe Edebiyat Kültür Eğitim Dergisi, 3(1), 153-166.

Tokatlı, Suzan Suzi ve Erdem Nas, Gönül (2012). Anamur Ağzından Derleme Sözlüğ̈̈’ne Katkılar. Diyalektolog Ulusal Sosyal Bilimler Dergisi, 5, 33-45.

Toker, Mustafa (2011). Derleme Sözlüğü ve Mersin Ağzı Sözlüğü'ne Tarsus Yöresinden Katkılar. Turkish Studies International Periodical For The Languages, 6(3), 1229-1249.

Topal, Erol (2018). Giresun Eynesil Ağzından Derleme Sözlüğü'ne Katkılar. Karadeniz Araştırmaları, XV(59), 291-296.

Turhan, Nurşah (2018). Trabzon Ağzından Derleme Sözlüğü' ne Katkılar, ASEAD, 5(2), 5358.

Türkiye'de Halk Ağzından Derleme Sözlüğü I-II-III-IV-V-VI, (Birleştirilmiş tıpkıbasım) (2009). Ankara: TDK Yayınları.

Türkiye'de Halk Ağzından Söz Derleme Dergisi, İstanbul: TDK Yayınları, , 1939-1949.

Uysal, İdris Nebi (2017). Kuzören (Konya-Bozkır) Köyü Ağzından Derleme Sözlügü̈’ne Katkılar. Diyalektolog Ulusal Hakemli Sosyal Bilimler Dergisi, 14, 79-85.

Uysal, İdris Nebi (2018). Himmetli (Niğde-Merkez) Köyü Ağzından Derleme Sözlüğü'ne Katkılar. ERDEM, 74, 139-156.

Korkut Ata Türkiyat Araştırmaları Dergisi
Uluslararası Türk Dili ve Edebiyatı Araştırmaları Dergisi
The Journal of International Turkish Language \& Literature Research
Sayı 5/ Ağustos 2021


Yeşilöz, Zafer (2012). Nevşehir Lakaplarından Derleme Sözlüğü'ne Katkılar, NEÜ SBE Dergisi, 2, 22-27.

Yıldız, Muharrem ve Özsoy, Yusuf (2016). Bartın Ağzından Derleme Sözlüğüne Katkılar, Bartın Üniv. Edebiyat Fakültesi Dergisi, 1(1), 141-150.

Yıldız, Osman (2007). Isparta Ağzından Derleme Sözlüğüne Katkılar. Turkish Studies International Periodical For The Languages, 2(2), 790-800.

Yılmaz, Kadir (2011). Yıldızeli'nin Söz Varlığı. Sivas: Cumhuriyet Üniv. SBE Yayımlanmamış Yüksek Lisans Tezi.

http://www.tdk.gov.tr; (Erişim Tarihi: 05.07.2021). 